\title{
En Marche!
}

\section{Researchers and their institutions must play their full part in ensuring that the exciting changes now sweeping France succeed.}

It is difficult to overstate the magnitude of political change in France of late, or where it might lead. But the election in May of Emmanuel Macron, a forward-looking progressive and fervent European, may represent the best chance that France and the Europe Union have had for decades. Research, innovation and higher education will be central to the success of Macron's ambitious agenda of modernizing and greening society.

In barely a year, Macron assembled a vast grassroots centrist movement, La République en Marche! (LREM), which in June completed Macron's demolition of the French political landscape by winning a commanding majority in parliamentary elections. LREM not only pushed aside the two mainstream centre-left and centre-right parties that had held a monopoly on power for decades - and pushed back the far right Front National - but has also renewed and rejuvenated the French political class.

Around half of LREM's elected deputies are women, and a majority come from civil society without previous political experience. They include academics, such as Cédric Villani, a mathematician and 2010 Fields medallist. That three-quarters of those elected to the 577-seat Assemblée Nationale are newcomers is unprecedented. There is a unique chance for change.

Science, education and innovation permeate much of Macron's agenda for modernizing France, boosting wealth creation, and tackling the country's chronic high unemployment. He has announced a $€ 10$-billion state fund for investing in startups - particularly in green technologies, robotics and artificial intelligence - and a €50-billion stimulus package for youth training and modernizing healthcare, agriculture, transport and infrastructure.

It is a good sign that higher education, science and innovation have been given a full ministry, and that the minister, Frédérique Vidal, a biologist and nowformer president of the University of Nice Sophia Antipolis, is someone with first-hand experience of issues facing universities and research, and not a career politician. Another minister, for Solidarity and Health, is Agnès Buzyn, a haematology researcher and physician with long experience in public health

Lending credibility to the government's ambitions to shift to a greener, lowcarbon economy is the appointment - as Minister for the Ecological and Inclusive Transition - of Nicolas Hulot, a highly popular environmental activist and former nature-documentary producer.

In response to US President

Donald Trump's announcement intending to withdraw from the Paris climate accord, Macron has moved swiftly to exert political leadership on combating climate change. He cleverly established a $€ 60$ million fund to attract around 50 international climate scientists to France under a programme cheekily named Make Our Planet Great Again. Similarly, Macron has offered fast-track four-year, renewable residence permits to leading researchers and entrepreneurs - and their families - to attract them to France.

Some researchers in France have scoffed at the initiatives, dismissing them as largely a public relations exercise, at a time when research funds at home are scarce. But they miss the point: Macron is already succeeding in branding France as a promising place to come and do research and to invest in startups and other companies, and any increase in foreign investment in private-sector innovation in France can only help create synergies and opportunities for its public research. Amid the doom and gloom of Trump's election and Brexit, France's international stature is enjoying a new shine, and in turn boosting French pride and optimism.

In line with the Paris accord, Hulot earlier this month announced measures to accelerate the transition to a low-carbon economy. These include ending the sale of petrol and diesel vehicles by 2040 , closing France's remaining coal-fired power plants by 2022 , and, as of this year, delivering no new oil- or gas-exploration licenses. France now aims to become carbon-neutral by 2050 .

More broadly, Macron wants to create an environment conducive to entrepreneurship by simplifying bureaucracy, reducing business costs, and making labour laws more flexible. The philosophy is that actors in civil

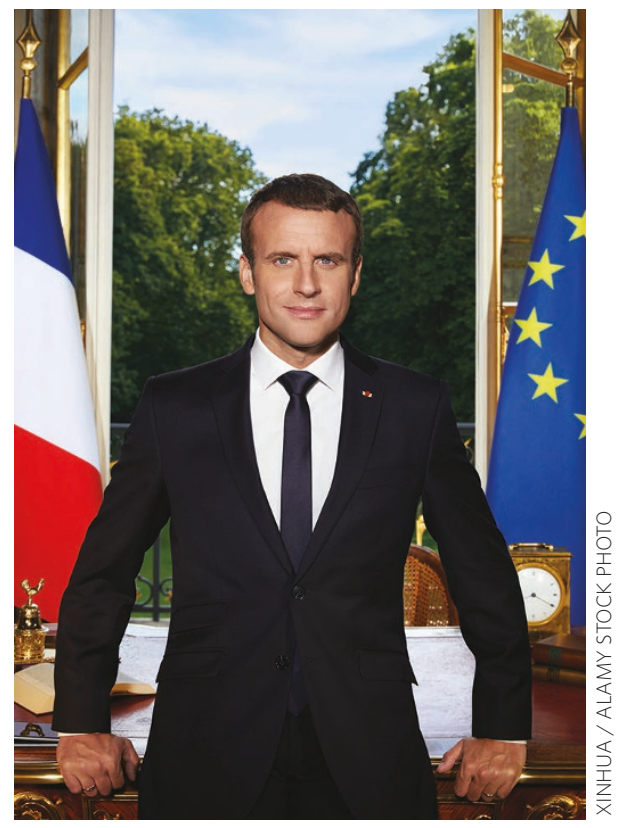

society, such as entrepreneurs, researchers, companies and universities, will flourish when freed to innovate and set their own strategies within their local context.

A series of reforms begun under President Nicolas Sarkozy (Nat. Mater. 6, $393 ; 2007)$ and continued by his successor François Hollande (Nat. Mater. 11, 559; 2012) have, over the past decade, given France's universities greater independence to develop their relations with industry and national research organizations. Clusters of excellence are emerging as a result.

With the government committed to steeply reducing its budget deficit as of this year, there may be few possibilities for an immediate increase in spending on research as a specific sector. Nonetheless, Macron's overall vision is strongly supportive of research and its role in society, and much of the $€ 50$ billion stimulus package, for example, is likely to have a strong research component.

Macron's administration deserves the benefit of the doubt - and time. He has already revitalized the country by putting fresh faces and fresh thinking at the helm of French politics - he would do well to do likewise throughout the leadership of the country's research system. 